lution of the southern Nagssugtoqidian boundary in the Itivdleq-Ikertôq region, West Greenland. Rapp. Grønlands geol. Unders. 89, 63-75.

Myers, J. S. 1984: The Nagssugtoqidian mobile belt of Greenland. In Kröner, A. \& Greiling, R. (edit.) Precambrian tectonics illustrated, 237-250. Stuttgart: E. Schweizerbart'sche Verlagsbuchhandlung.

Myers, J. S., Austrheim, H., Gill, R. C. O., Gorman, B. E. \& Rex, D. C. 1979: Field work on the Nagssugtoqidian boundary north of Angmagssalik and Tertiary igneous rocks of Kialineq and Kap Gustav Holm, East Greenland. Rapp. Grønlands geol. Unders. 95, 82-85.

Pedersen, S. \& Bridgwater, D. 1979: Isotopic re-equilibration of Rb-Sr whole rock systems during reworking of Archaean gneisses in the Nagssugtoqidian mobile belt, East Greenland. Rapp. Grønlands geol. Unders. 89, 133-146.

Ramberg, H. 1948: On the petrogenesis of the gneiss complexes between Sukkertoppen and Christianshaab, West Greenland. Meddr dansk geol. Foren. 11, 312-327.

Taylor, P. N., Jones, N. W. \& Moorbath, S. 1984: Isotopic assessment of relative contributions from crust and mantle sources to the magma genesis of Precambrian granitoid rocks. Phil. Trans. R. Soc. Lond. A 310, 605-625.

Thorning, L. 1986: A decade of geophysical surveying in Greenland. Rapp. Grønlands geol. Unders. 128, 123-133.

Wager, L. R. 1934: Geological investigations in East Greenland. Part 1. General geology from Angmagsalik to Kap Dalton. Meddr Grønland 105(2), $46 \mathrm{pp}$.

Wright, A. E., Tarney, J., Palmer, K. F., Moorlock, B. S. P. \& Skinner, A. C. 1973: The geology of the Angmagssalik area, East Greenland and possible relationships with the Lewisian of Scotland. In Park, R. G. \& Tarney, J. (edit.) The early Precambrian of Scotland and related rocks of Greenland, 157-177. Univ. Keele.

\title{
Reconnaissance for economic minerals in the Kangerdlugssuaq area, East Greenland
}

\author{
C. K. Brooks, H.-K. Schønwandt and G. Stenstrop
}

As an intergral part of GGU's work in East Greenland in 1986 (Kalsbeek \& Nielsen, this report) a party visited the Kangerdlugssuaq area with a view to assessing its economic potential. Logistic support was shared with the Geodetic Institute. During most of the period spent in the field area (27 July to 12 August) Stenstrop, assisted by Henrik Krarup (a student assistant), worked on Flammefjeld, a porphyry molybdenum prospect earlier investigated by the Northern Mining Company of Copenhagen (Geyti \& Thomassen, 1984), while Brooks and Schønwandt investigated other targets and co-operated closely with Platinova Resources Ltd of Toronto who have a concession in the area.

Kangerdlugssuaq is an area of Archaean gneisses which was subject to intense magmatic activity in the early Tertiary when the present continental margin was located over the hot spot which now lies under Iceland. The geology has recently been reviewed by Brooks \& Nielsen (1982), where localities mentioned here can be identified.

Flammefjeld is a $600 \times 800 \mathrm{~m}$ subvolcanic complex intruding syenites of the Kangerdlugssuaq intrusion and its satellite, the Snout Series. It consists of a breccia pipe containing fragments of the host syenite in its various forms and also fragments of felsite porphyry 
which also occurs cutting the surrounding syenites. These rocks were later intruded by a quartz porphyry and finally by a hydrothermal breccia. Striking colour anomalies are present which are due to extensive zones of argillaceous and local phyllic alteration. Molybdenite occurs in the late hydrothermal breccia. Zones of vein-type mineralization with base metal sulphides occur outside the immediate complex and were previously reported to have high gold and silver values. During the course of this work, similar veins were located further away from Flammefjeld suggesting that they may extend throughout the region.

This season's work led to a revision of the model for the genesis of the Flammefjeld complex. It was formed by two cycles of activity whereby a granitic magma rose to high levels and chilled to form the felsite porphyries. With further crystallization and temperature fall, secondary boiling led to an explosive release of pressure to form the breccia pipe. The second cycle proceeded in a similar manner but was terminated by a less violent loss of the vapour phase and possibly by interaction with meteoric waters leading to mineralization and extensive alteration. This was terminated by a hydrothermal explosive phase which brecciated all earlier formed rocks including those which had been mineralized. Mafic inclusions in the Snout Series syenites, which were earlier thought to be xenoliths from the overlying (now removed) basalts, are at least in part injections of mafic magma into unconsolidated syenites, raising the interesting possibility that explosive activity may have been triggered by basaltic magma in the manner described by Sparks et al. (1977).

Outside Flammefjeld the main interest lay in possible platinum group metal (PGM) concentrations in the extensive mafic and ultramafic bodies in the area. Sulphide-rich horizons have long been known in the Skaergaard Intrusion (Wager \& Brown, 1968) and several thin, malachite-stained concordant layers were located in the Kap Edward Holm upper layered series. In addition, sulphide blebs occur in the Mikis Fjord macrodike in positions where they are believed to have accumulated on shallow-dipping contacts with the gneisses. Members of a Stanford University expedition working in the area drew our attention to sulphiderich gabbro adjacent to a melted gneissic intrusion in the Skaergaard Intrusion and to traces of native copper in volcanic rocks metamorphosed to greenschist facies. Samples of these materials have been collected for PGM and base metal assays.

Regional hydrothermal dykes consisting of carbonate, carbonate-altered gneiss and siliceous material are generally barren of macroscopic sulphide minerals, although close to Flammefjeld they may contain galena and manganese oxides. These bodies are shallow hydrothermal conduits with abundant and open spaces, and may be extinct hot spring deposits formed in geothermal areas similar to those at present active to the north. They are possible targets for gold mineralization.

Several colour anomalies identified from satellite imagery were investigated. At Kærven this was found to be caused by reddish weathering fayalite-bearing syenite, while others were caused by the previously mentioned quartz-carbonate veins. At Nordfjord an extensive colour anomaly is caused by alteration of basement gneisses, often giving an apparently fresh, but brick-red alkali feldspar. At this locality grains of molybdenite occur in the amphibolitic layers, suggesting that the concentrations at Flammefjeld of Tertiary age may derive from earlier anomalously enriched Precambrian basement. A similar alteration zone was visited at the head of Watkins Fjord, but no molybdenite mineralization was observed here.

Ultramafic rocks occur round Kærven and these occasionally contain concentrations of chromite, although no major deposits were found. These bodies will also be assayed for PGMs. 
A new discovery was an extensive (about $400 \mathrm{~m}$ across) zone of basic amphibole-rich rocks along Nordre Syenitgletscher. These rocks are strongly mineralized (mainly pyrite) and will be studied in the laboratory. Extensive zones of alteration associated with acid volcanic rocks were investigated on Kap Edward Holm, Barberkniven and a nunatak in Søndre Syenitgletscher.

Brooks accompanied by Krarup made a short trip to the Lilloise Complex located at approximately $68^{\circ} 30^{\prime} \mathrm{N}, 28^{\circ} 50^{\prime} \mathrm{W}$. This has earlier been described as a layered gabbro (Brown, 1973), but was found by us to be much more complicated with extensive areas of peridotitic rocks, highly laminated hornblende gabbros with a very steep dip, and an intense thermal aureole. Stream-sediment samples collected on glaciers here yielded high concentrations of sulphides, and a wide carbonate-quartz vein similar to those in the Kangerdlugssuaq intrusion contains sparse copper sulphides and has been chip-sampled.

It had been our original plan to investigate a number of mafic bodies to the south: the Kruuse Fjord gabbro $\left(67^{\circ} 19^{\prime} \mathrm{N}, 33^{\circ} 40^{\prime} \mathrm{W}\right)$, Nualik, immediately to the east of this, and Imlik $\left(66^{\circ} 40^{\prime} \mathrm{N}, 33^{\circ} 50^{\prime} \mathrm{W}\right)$, in the Kialineq Centre. However, this was done only superficially because of the extremely severe terrain and logistic problems. Interesting acid volcanics were investigated west of Kap Warming in the Kialineq Centre, but proved very difficult to approach by helicopter and only one rather unsatisfactory landing could be made.

In summary, the Flammefjeld Complex resembles classic porphyry molybdenum deposits such as Mt. Emmons (Thomas \& Galey, 1982), as well as nearby Malmbjerg and the riftrelated deposits of the Oslo graben (Schønwandt \& Petersen, 1983), and we now have a better understanding of its structure and genesis. Our work also located several interesting targets for PGMs and gold mineralization for which assay results must be awaited. Stream sediments were also collected in interesting areas, but at present no results are available.

\section{References}

Brooks, C. K. \& Nielsen, T. F. D. 1982: The Phanerozoic development of the Kangerdlugssuaq area, East Greenland. Meddr Grønland, Geosci. 9, 30 pp.

Brown, P. E. 1973: A layered plutonic complex of alkali basalt parentage: the Lilloise intrusion, East Greenland. J. geol. Soc. Lond. 129, 405-418.

Geyti, A. \& Thomassen, B. 1984: Molybdenum and precious metal mineralization at Flammefjeld, southeast Greenland. Econ. Geol. 79, 1921-1929.

Schønwandt, H. K. \& Petersen, J. S. 1983: Continental rifting and porphyry molybdenum occurrences in the Oslo Region, Norway. Tectonophysics 94, 609-631.

Sparks, R. S. J., Sigurdsson, H. \& Wilson, L. 1977: Magma mixing: a mechanism for triggering acid explosive eruptions. Nature, Lond. 267, 315-318.

Thomas, J. A. \& Galey, J. T. 1982: Exploration and geology of the Mt. Emmons molybdenite deposits, Gunnison County, Colorado. Econ Geol. 77, 1085-1184.

Wager, L. R. \& Brown. G. M. 1968: Layered igneous rocks. Edinburgh: Oliver \& Boyd, 588 pp.

C. $K . B$.

Institut for Petrologi,

Københavns Universitet,

$\emptyset$ ster Voldgade 10,

DK-1350 Copenhagen $K$,

Denmark.
H. $-K . S . \& G . S$,

Geologisk Institut, Aarhus Universitet, DK-8000 Århus C, Denmark. 